\title{
Kallikrein-like amidase activity in renal ischemia and reperfusion
}

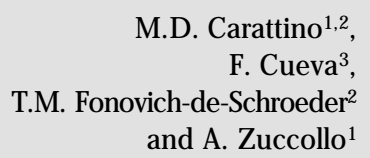

\author{
IPROSIVAD-CONICET, Cátedra de Fisiología, Facultad de Farmacia y Bioquímica, \\ Universidad de Buenos Aires, Buenos Aires, Argentina \\ ${ }^{2}$ Universidad Nacional de General San Martín, San Martín, Argentina \\ ${ }^{3}$ Hospital Israelita, Buenos Aires, Argentina
}

\author{
Correspondence \\ M.D. Carattino \\ Cátedra de Fisiología, PROSIVAD \\ Facultad de Farmacia y Bioquímica \\ Universidad de Buenos Aires \\ Junín 956, piso 7 \\ 1113 Buenos Aires \\ Argentina \\ Fax: + 54-1-4964-0667 \\ E-mail: \\ teresa.fonovich@unsam.edu.ar
}

Research supported by CONICET (No. 0071-PIC-BID) and Fundación Barceló.

Received January 25, 1999 Accepted February 2, 2000

\section{Abstract}

We assessed a kallikrein-like amidase activity probably related to the kallikrein-kinin system, as well as the participation of leukocyte infiltration in renal ischemia and reperfusion. Male C57BL/KSJmdb mice were subjected to 20 or $60 \mathrm{~min}$ of ischemia and to different periods of reperfusion. A control group consisted of sham-operated mice, under similar conditions, except for ischemia induction. Kallikrein-like amidase activity, Evans blue extravasation and myeloperoxidase activity were measured in kidney homogenates, previously perfused with $0.9 \% \mathrm{NaCl}$. Plasma creatinine concentration increased only in the 60-min ischemic group. After 20 min of ischemia and 1 or $24 \mathrm{~h}$ of reperfusion, no change in kallikrein-like amidase activity or Evans blue extravasation was observed. In the mice subjected to 20 min of ischemia, edema was evident at $1 \mathrm{~h}$ of reperfusion, but kidney water content returned to basal levels after $24 \mathrm{~h}$ of reperfusion. In the 60-min ischemic group, kallikrein-like amidase activity and Evans blue extravasation showed a similar significant increase along reperfusion time. Kallikrein-like amidase activity increased from $4 \mathrm{nmol}$ PNA mg protein ${ }^{-1} \mathrm{~min}^{-1}$ in the basal condition to $15 \mathrm{nmol}$ PNA mg protein $^{-1} \mathrm{~min}^{-1}$ at $10 \mathrm{~h}$ of reperfusion. For dye extravasation the concentration measured was near $200 \mu \mathrm{g}$ of Evans blue/g dry tissue in the basal condition and $1750 \mu \mathrm{g}$ of Evans blue/g dry tissue at $10 \mathrm{~h}$ of reperfusion. No variation could be detected in the control group. A significant increase from 5 to 40 units of $\Delta \mathrm{Abs} 655 \mathrm{~nm} \mathrm{~g}$ wet tissue ${ }^{-1}$ $\mathrm{min}^{-1}$ in the activity of the enzyme myeloperoxidase was observed in the 60-min ischemic group, when it was evaluated after $24 \mathrm{~h}$ of reperfusion. Histological analysis of the kidneys showed migration of polymorphonuclear leukocytes from the vascular bed to the interstitial tissue in the 60-min ischemic group after $24 \mathrm{~h}$ of reperfusion. We conclude that the duration of ischemia is critical for the development of damage during reperfusion and that the increase in renal cortex kallikrein-like amidase activity probably released from both the kidney and leukocytes may be responsible, at least in part, for the observed effects, probably through direct induction of increased vascular permeability.
Key words

- Kidney

- Ischemia-reperfusion

- Kallikrein

- Vascular permeability

- Leukocyte infiltration 


\section{Introduction}

Damage produced by ischemic disorders has been recently studied in different organs but some of the alterations described have not been strictly attributed to the ischemia suffered by the organ (1-4). The role of neutrophils in post-ischemic damage has been studied in myocardium (5), kidney (1), intestine (2), brain (6) and pancreas (4). Hoffman et al. (4) reported that ischemia followed by reperfusion is responsible for the breakdown of the microcirculation in the pancreas and considered this event as a critical factor in the pathogenesis of acute pancreatitis. Romson et al. (7) demonstrated that oxygen radicals are involved in the pathogenesis of myocardial infarction and that inflammatory neutrophils are a major source of oxygen radicals. Cell membrane disintegration is the consequence of both the formation of biologically dangerous free radicals through an enhanced activity of xanthine oxidase and leukocyte interaction with the microvascular endothelial cells in the intestine (2). Grisham et al. (2) suggested a relationship between xanthine oxidase-generated $\mathrm{O}_{2}{ }^{-}$and neutrophil infiltration. Experiments involving ischemia and reperfusion of coronary arteries revealed that the endothelium was activated. Under these conditions, endothelial cells were able to release several factors such as interleukin- 8 and platelet activating factor, that act as either chemotactic or activating factors for neutrophils $(5,8,9)$. Nitric oxide (NO) has also been shown to mediate leukocyteendothelial cell interactions. Several studies have demonstrated that NO concentration increases during ischemia and decreases upon reperfusion, thus facilitating the binding of neutrophils to the endothelium during the latter period $(5,10)$.

According to Weight et al. (1), activated polymorphonuclear cells can cause kidney damage by three different pathways: 1) production of free radicals through the respiratory burst, 2) release of intrinsic en- zymes, and 3) physical obstruction of capillaries. The kallikrein-kinin system and other proteases have been involved in the regulation of vascular permeability both under physiological conditions and in different pathologies (11). Semerciöz et al. (12) demonstrated that the administration of ramipril (an angiotensin-converting enzyme inhibitor) exacerbates the deleterious effect of ischemia in the kidney. They also suggested that the observed effect may involve an increase in kinin production. The present study was performed to correlate the appearance of a kallikrein-like amidase activity in homogenates of renal cortex with probable alterations of the microcirculation produced in the kidney by ischemia and reperfusion.

\section{Material and Methods}

All experiments were performed with C57BL/KSJmdb mice weighing 20-25 g each, supplied by the Genetic National Institute of Buenos Aires. The animals were housed at room temperature, on a 12-h light-dark cycle, with free access to tap water and mouse chow. Separate groups of five or six mice each were subjected to a specific pair of conditions (ischemia-reperfusion), and amidase activity, Evans blue extravasation, kidney water content and myeloperoxidase activity were determined for each situation.

\section{Ischemia induction}

Surgery was carried out under ether anesthesia, in agreement with international rules for the use of experimental animals provided by the National Institutes of Health, USA. The left renal pedicles of the mice were clamped through an abdominal incision. After 20 or $60 \mathrm{~min}$ the clamp was removed and contralateral nephrectomy was carried out. A control group was sham operated under similar conditions, except for ischemia induction. 


\section{Tissue water content}

After reperfusion the animals were anesthetized and sacrificed by cervical dislocation and the kidney was removed, decapsulated and weighed. Tissue samples were dried at $105^{\circ} \mathrm{C}$ for $48 \mathrm{~h}$ and weighed again (13). The percentage of tissue water content was calculated (13).

\section{Creatinine concentration}

Plasma was prepared from blood obtained by cardiac puncture under anesthesia. Creatinine concentration was determined with a commercial kit (Biosystems, Barcelona, Spain) and reported as $\mathrm{mg}$ creatinine/dl plasma.

\section{Kallikrein-like amidase activity}

The kidneys were perfused with $0.9 \%$ $\mathrm{NaCl}$ and immediately frozen at $-20^{\circ} \mathrm{C}$. The renal cortex was sectioned, weighed and homogenized in 40 volumes of $10 \mathrm{mM}$ Tris buffer, $\mathrm{pH} 7.4$, per gram of tissue. Homogenates were obtained in a cold water bath with a Teflon-glass homogeneizer. Sodium deoxycholate was added to a final concentration of $0.2 \%$ and homogenates were incubated for $30 \mathrm{~min}$ at $4^{\circ} \mathrm{C}$. The samples were then centrifuged at $12,000 \mathrm{~g}$ for $60 \mathrm{~min}$ at $4^{\circ} \mathrm{C}$ and supernatants were filtered through Sephadex G-25 to remove salts and detergent. The eluted fraction was used for the assay of kallikrein amidase activity and protein.

Amidolytic activity was determined by incubating $0.1 \mathrm{ml}$ of homogenate with $1.5 \mathrm{mM}$ D-Val-Leu-Arg-paranitroaniline(S2266, Chromogenix, Mölndal, Sweden), $20 \mathrm{mM}$ soybean trypsin inhibitor (SBTI) and $0.2 \mathrm{M}$ Tris buffer, $\mathrm{pH} 9.5$, in a final volume of $1 \mathrm{ml}$, for $30 \mathrm{~min}$ at $37^{\circ} \mathrm{C}$. The reaction was stopped with $0.1 \mathrm{ml}$ of $50 \%$ acetic acid. Samples were centrifuged at $10,000 \mathrm{~g}$ for $15 \mathrm{~min}$ at $4^{\circ} \mathrm{C}$ and precipitated proteins were discarded. Blanks were performed under similar conditions but the reac- tion was stopped at 0 time. The color developed during incubation was determined by absorbance measurements at $405 \mathrm{~nm}$ and enzyme activity was reported as nmol pnitroaniline released per minute per $\mathrm{mg}$ protein (14). Protein concentration in the supernatant was measured by the method of Bradford (15) using bovine serum albumin as standard. Determinations were carried out in duplicate.

\section{Vascular permeability}

One hour before sacrifice the mice were anesthetized with ether and injected intravenously with $2.5 \mathrm{ml}$ Evans blue (EB) dye (1\% in $0.9 \% \mathrm{NaCl}$ solution) per $\mathrm{kg}$ body weight through the jugular vein. One hour after the injection the mice were anesthetized and decapitated, and then perfused with physiological solution through the thoracic aorta until elimination of all blood. The kidneys were excised, decapsulated, dried by centrifugation at $25^{\circ} \mathrm{C}$ under vacuum and weighed in order to estimate dry weight. The kidneys were homogenized in $2 \mathrm{ml}$ of dimethylformamide, incubated at $55^{\circ} \mathrm{C}$ for 18 $\mathrm{h}$, and then centrifuged at $10,000 \mathrm{~g}$ for 15 $\min$ at $4^{\circ} \mathrm{C}$. The amount of EB in the supernatant was determined by measuring absorbance at $635 \mathrm{~nm}$ and corrected for the extraction volume. A standard curve of EB in dimethylformamide was constructed (16).

\section{Myeloperoxidase activity}

The kidneys of a group of mice subjected to ischemia and reperfusion were perfused, excised and decapsulated as described above, weighed on an analytical balance to determine wet weight and frozen. Three freezingthawing cycles were performed with sonication for $10 \mathrm{~s}$ at $25^{\circ} \mathrm{C}$. Renal tissue was homogenized in 10 volumes of $50 \mathrm{mM}$ phosphate buffer, $\mathrm{pH} 5.4$, and $0.5 \%$ hexadecyltrimethylammonium bromide. The samples were incubated at $4^{\circ} \mathrm{C}$ for $20 \mathrm{~min}$ and centrifuged at 12,000 $\mathrm{g}$ for $45 \mathrm{~min}$ (17). 
Myeloperoxidase activity was assayed using 3,3',5,5'-tetramethylbenzidine (TMB) as substrate. Aliquots of $0.1 \mathrm{ml}$ of the supernatant were mixed with $0.9 \mathrm{ml}$ of buffer to obtain a final concentration of $0.3 \mathrm{mM} \mathrm{H}_{2} \mathrm{O}_{2}$, $1.6 \mathrm{mM}$ TMB, 4\% dimethylformamide and $80 \mathrm{mM}$ phosphate buffer, $\mathrm{pH}$ 5.4. The absorbance was measured at $655 \mathrm{~nm}$ and $25^{\circ} \mathrm{C}$ with a Shimadzu spectrophotometer and recorded for 1 min each starting after $30 \mathrm{~s}$. Results are reported as $\Delta \mathrm{Abs} 655 \mathrm{~nm} \mathrm{~g}$ wet tissue $\mathrm{e}^{-1} \mathrm{~min}^{-1}(18)$.

\section{Histological analysis}

The kidneys of ischemic-reperfused (60

Figure 1 - Effect of reperfusion time on Evans blue extravasation (A), kallikrein-like amidase activity (B) and kidney water content $(C)$ in mice previously subjected to $20 \mathrm{~min}$ of renal ischemia and in sham-operated animals. Results are reported as the means \pm SEM of duplicate samples obtained from at least five animals. ANOVA: ap<0.01 between sham and ischemic mice (Bonferroni post-hoc test). PNA, p-nitroaniline.
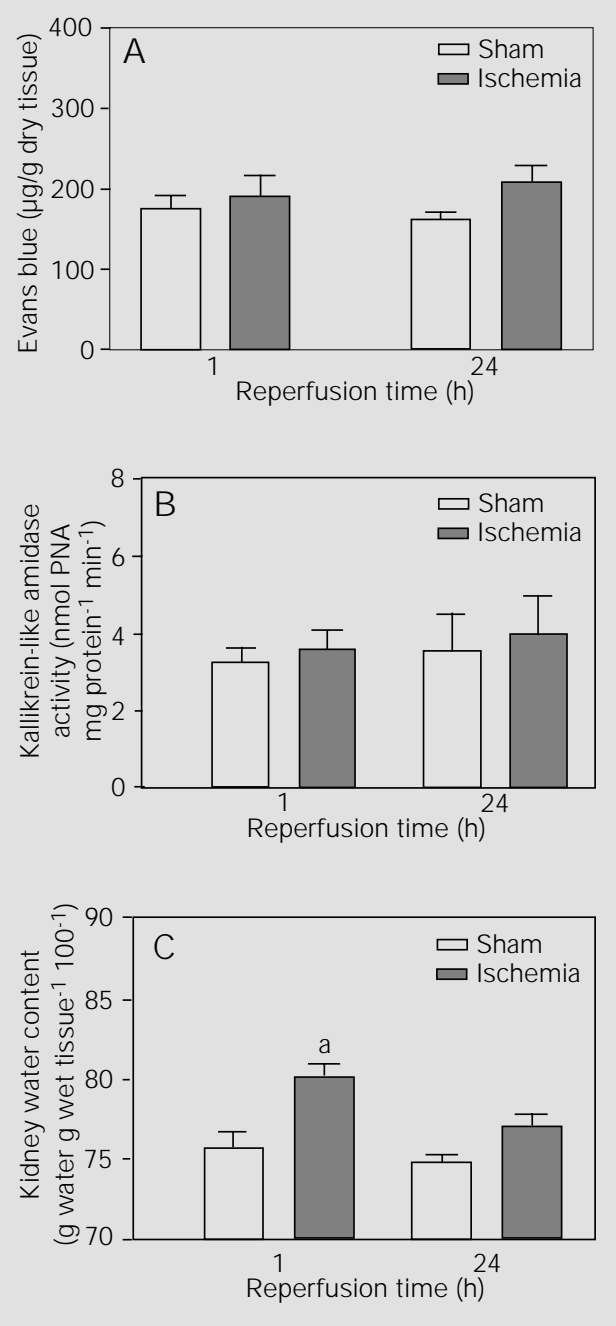

min and $24 \mathrm{~h}$ ) and sham-operated mice were fixed in Lillie's formalin and embedded in paraffin. Five- $\mu \mathrm{m}$ slices were stained with hematoxylin-eosin and photomicrographs were taken at $100 \mathrm{X}$.

\section{Statistical analysis}

All data are reported as means \pm SEM. Groups were compared by multiple analysis of variance followed by the Bonferroni posthoc test. When differences between variances were high, the Kruskal-Wallis test was performed followed by Dunn's multiple comparisons test. $\mathrm{P}<0.05$ was considered statistically significant.

\section{Results}

The purpose of the present study was to evaluate different factors inherent to microcirculation in a model of kidney ischemia and reperfusion. Vascular permeability, kallikrein-like amidase activity, plasma creatinine concentration and tissue water content were studied after different periods of ischemia (20 or $60 \mathrm{~min}$ ) and reperfusion (1 or 24 h). While the first three parameters did not show significant changes after $20 \mathrm{~min}$ of ischemia and 1 or $24 \mathrm{~h}$ of reperfusion, kidney water content exhibited a significant increase in the group of mice subjected to 20 min of ischemia and $1 \mathrm{~h}$ of reperfusion (Figure 1).

Table 1 shows the plasma creatinine concentrations of sham-operated and ischemic groups of mice after $24 \mathrm{~h}$ of reperfusion. A significant increase in plasma creatinine concentration was detected in the mice subjected to $60 \mathrm{~min}$ of ischemia and $24 \mathrm{~h}$ of reperfusion compared to all other groups (Bonferroni multiple comparisons test: $\mathrm{P}<0.001)$.

The vascular permeability and tissue kallikrein-like amidase activity for the groups of mice subjected to $60 \mathrm{~min}$ of ischemia and $1,3,10$ or $24 \mathrm{~h}$ of reperfusion are shown in 
Figure 2. Kidney water content was evaluated in mice subjected to $60 \mathrm{~min}$ of ischemia only after 1 or $24 \mathrm{~h}$ of reperfusion (Figure 2C). Similar patterns can be observed for both EB extravasation and kallikrein-like amidase activity, which exhibited progressive significant increments in ischemic mice during the initial $10 \mathrm{~h}$ of reperfusion, followed by a decrease. Sham-operated animals did not show changes in either parameter at any of the reperfusion periods studied (Figure 2A and B). Sixty minutes of ischemia and 1 or $24 \mathrm{~h}$ of reperfusion caused significant increments in kidney water content when compared with tissue water contents measured in the sham-operated animals.

Myeloperoxidase activity was measured in renal tissue as a marker of neutrophil infiltration (17) (Figure 3). The activity of the enzyme was measured after $24 \mathrm{~h}$ of reperfusion in mice previously subjected to 20 or $60 \mathrm{~min}$ of ischemia. While no difference could be detected after 20 min of ischemia, a significant increase in enzyme activity was evident after $60 \mathrm{~min}$ of ischemia.

Figure 4 shows photomicrographs of ischemic-reperfused as well as sham-operated mouse kidneys. The renal tissue of $60-\mathrm{min}$ ischemic mice that were reperfused for $24 \mathrm{~h}$ exhibited submassive tubular necrosis and endothelial micronecrosis with vascular congestion. The margination and later migration of polymorphonuclear leukocytes from the vascular bed to the interstitial tissue was also evident. These results correlate well with the myeloperoxidase activity measured in the ischemic-reperfused mouse kidneys and suggest active participation of leukocytes in the ischemia-reperfusion process.

\section{Discussion}

Early restoration of blood flow to ischemic tissues is essential to halt the progression of cellular injury associated with decreased oxygen and nutrient delivery. It is clear that reperfusion of ischemic tissues initiates a complex series of reactions that paradoxically damage tissues $(5,19,20)$. Even though several mechanisms have been pro-

Table 1 - Effect of ischemia time on serum creatinine levels in sham-operated and ischemic mice after $24 \mathrm{~h}$ of reperfusion.

Data are reported as mean \pm SEM for five or six mice per group. $* \mathrm{P}<0.001$ between groups (Bonferroni multiple comparisons test).

\begin{tabular}{|c|c|c|}
\hline \multirow[t]{2}{*}{ Time (h) } & \multicolumn{2}{|c|}{ Serum creatinine (mg/dl) } \\
\hline & Sham & Ischemia \\
\hline 20 & $0.452 \pm 0.061$ & $0.510 \pm 0.110$ \\
\hline 60 & $0.402 \pm 0.030$ & $1.817 \pm 0.138^{*}$ \\
\hline
\end{tabular}
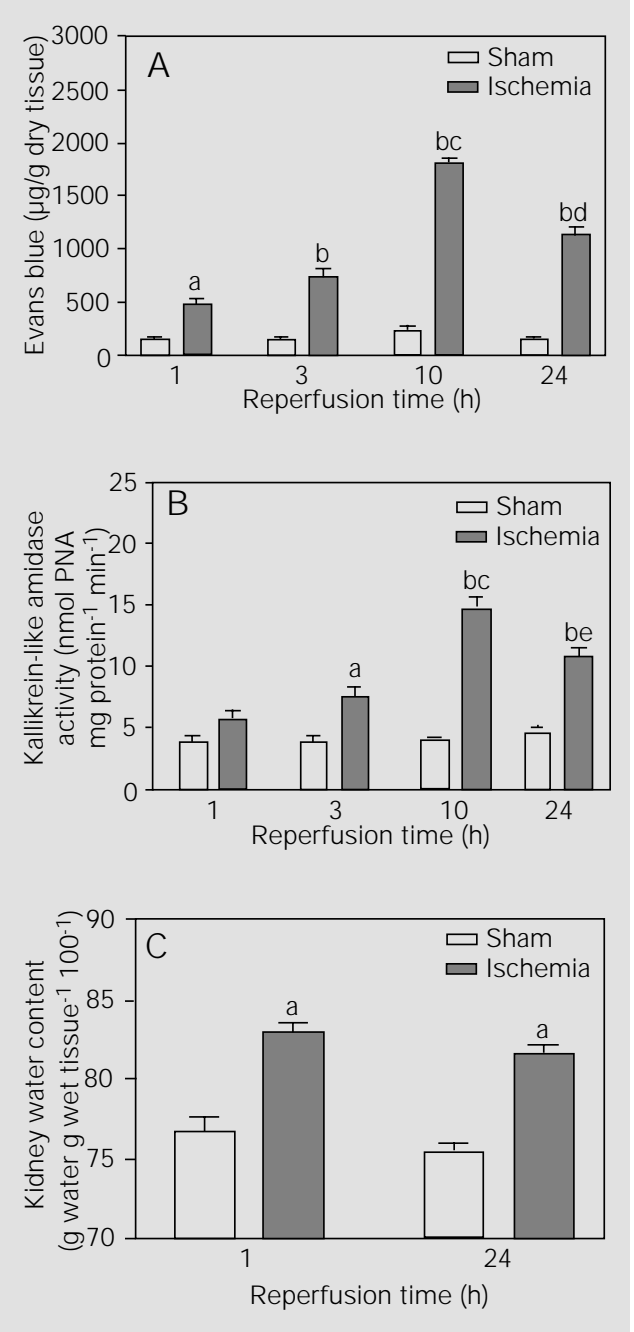

Figure 2 - Effect of reperfusion time on Evans blue extravasation (A), kallikrein-like amidase activity (B) and kidney water content $(C)$ in mice previously subjected to $60 \mathrm{~min}$ of renal ischemia and in sham-operated animals. Results are reported as the means \pm SEM of duplicate samples obtained from at least five animals. ANOVA (Bonferroni post-hoc test): ap $<0.01$ between sham and ischemic mice; bP $<0.001$ between sham and ischemic mice; $\mathrm{CP}<0.001$ between 10 and 1,3 or $24 \mathrm{~h}$ of reperfusion in ischemic mice; $\mathrm{dP}<0.001$ between 10 and 1 or $3 \mathrm{~h}$ of reperfusion in ischemic mice for Evans blue extravasation; eP $<0.001$ between 24 and $1 \mathrm{~h}$ of reperfusion, $\mathrm{P}<0.05$ between 24 and $3 \mathrm{~h}$ of reperfusion for kallikrein-like amidase activity. PNA, p-nitroaniline. 
Figure 3 -Effect of ischemia time on myeloperoxidase activity in the kidney after different periods of ischemia (20 or $60 \mathrm{~min}$ ) and $24 \mathrm{~h}$ of reperfusion. Results are reported as the means \pm SEM of duplicate samples obtained from at least five animals. ANOVA: aP $<0.05$ between sham and ischemic mice (Dunn's multiple comparisons test).

Figure 4 - Histological analysis of renal tissue from control mice (not reperfused) (A) and from mice subjected to $60 \mathrm{~min}$ of ischemia and $24 \mathrm{~h}$ of reperfusion (B and C). Sections of $5 \mu \mathrm{m}$ were stained with hematoxylin-eosin and photomicrographs were taken at 100X. B, Submassive tubular necrosis with intense leukocyte infiltration and capillary congestion can be observed. C, Tubular necrosis with incoming leukocyte interstitial exudation is also visible. posed to explain the pathogenesis of ischemia-reperfusion injury, most attention has been focused on the role of reactive oxygen metabolites and some mediators of the inflammatory process (19-21).
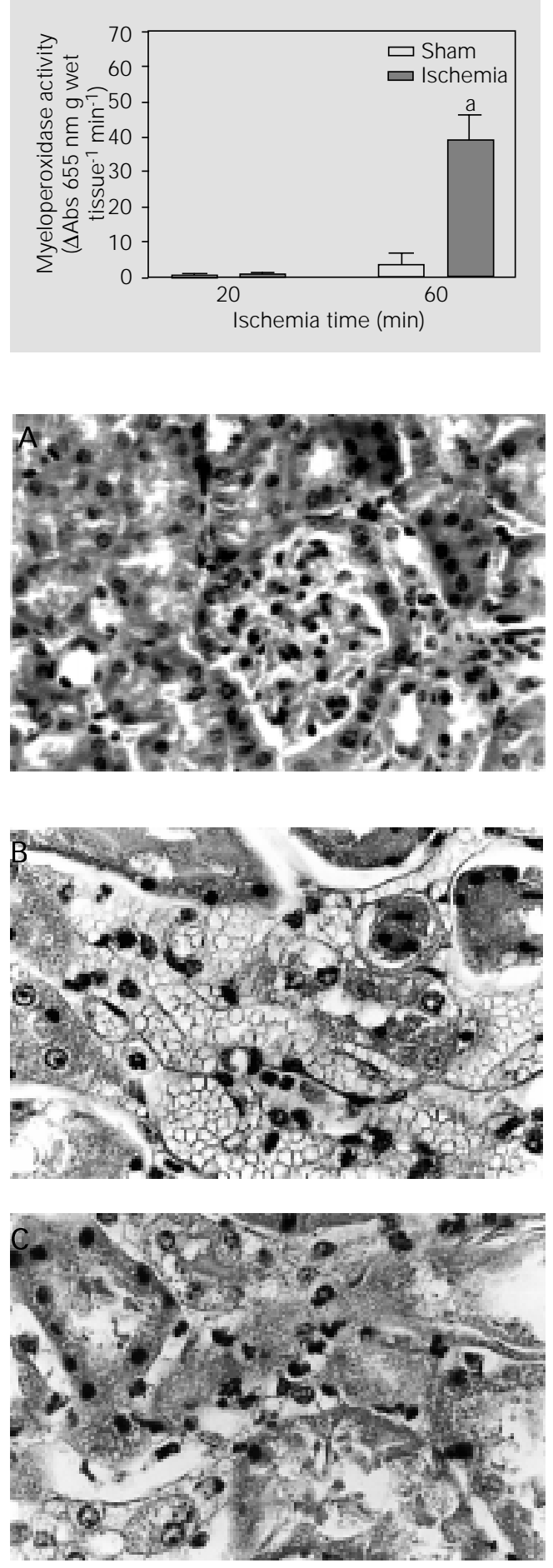

Tissue kallikrein is secreted from different sources and acts on low molecular weight kininogen to generate lysyl-bradykinin (kallidin), which is rapidly converted to bradykinin. On the other hand, plasma kallikrein directly liberates bradykinin from a high molecular weight kininogen through a cascade that involves previous conversion of coagulation factors (22-24). Under physiological conditions the kallikrein-kinin system has been implicated in the control of renal blood flow and of electrolyte and water transport (25).

Our results demonstrate that short periods of ischemia followed by reperfusion did not cause alterations in kidney homogenate kallikrein-like amidase activity, Evans blue extravasation, plasma creatinine or myeloperoxidase activity (Figures 1 and 3). On the other hand, edema was evident after a short period of ischemia $(20 \mathrm{~min})$ and a short period of reperfusion, thus confirming this as an early event in the pathogenesis of ischemia-reperfusion injury (Figure 1). These results suggest that a short period of ischemia followed by reperfusion transiently induced edema. Under such ischemia conditions, kidney water content slightly increased at $1 \mathrm{~h}$ of reperfusion and returned to basal values after prolonged reperfusion. Occurrence of leukocyte infiltration was unlikely since myeloperoxidase activity remains near zero and renal function should probably remain unchanged. More sensitive assays such as inulin and p-aminohippurate clearance should be more sensitive than plasma creatinine concentration in clarifying the status of renal function after short periods of reperfusion. Further investigations should include these approaches.

A longer period of ischemia followed by different periods of reperfusion caused increased kidney kallikrein-like amidase activity and Evans blue extravasation, with the highest responses being obtained after $10 \mathrm{~h}$ of reperfusion. Increases in tissue water content were also evident after a long period of 
ischemia and after 1 and $24 \mathrm{~h}$ of reperfusion, but at higher levels than those observed in the 20-min ischemic kidneys. The almost identical patterns in Evans blue extravasation and kallikrein-like amidase activity responses constitute strong evidence for a relationship between the measured kidney amidolytic activity and permeability of the capillary membranes in the ischemic-reperfused kidney. Histological examination of control and ischemic-reperfused kidneys (60 $\mathrm{min}$ and $24 \mathrm{~h}$ ) revealed dramatic alterations in the latter group, including leukocyte infiltration, submassive tubular necrosis and capillary congestion (Figure 4). These results are consistent with a role for kinin release in the initiation of damage caused by reperfusion of renal tissue previously subjected to ischemia for a long period of time (60 $\mathrm{min})$, as also reported by Bhoola (26).

Which was the main source of the amidolytic activity that we measured? Bhoola et al. (25) measured kallikrein activity in human neutrophils and Rothschild and Castania (27) indicated the presence of a kinin-generating enzyme system in rat granulocytes. Bhoola (26) reported a role for bradykinin released from neutrophil kininogen as a key mediator of an inflammatory process, especially through promotion of venule constriction and increases in capillary membrane permeability. In addition, the expression of a kinin- generating member of mouse glandular kallikrein was detected in mouse kidney (28). We performed our studies in the presence of soybean trypsin inhibitor, which, at a concentration of $2 \mathrm{mg} / \mathrm{ml}$, caused $73.3 \%$ of inhibition of the amidase activity of human leukocyte extracts (20) and which did not inhibit glandular (renal) kallikreins (29). Thus, we cannot rule out the possibility that our results could probably represent additive activities of both renal and leukocyte enzymes. Future studies in the presence of SBTI + EDTA + aprotinin should be performed to evaluate independently renal kallikrein-like amidase activities from leukocyte or other proteases (29).

We conclude from our experiments that the duration of ischemia is critical for the development of damage during reperfusion. Increased kallikrein-like amidase activity from renal tissue and/or neutrophils could probably be involved in the inflammatory process at least in part through direct induction of increased vascular permeability. Interleukin, prostaglandin and leukotriene synthesis is stimulated in different tissues by the kallikrein-kinin system (26). More specific assays should be performed to determine if these substances are formed and contribute to the inflammatory process in our ischemiareperfusion model.

\section{References}

1. Weight SC, Bell PRF \& Nicholson ML (1996). Renal ischaemia-reperfusion injury. British J ournal of Surgery, 83: 162170.

2. Grisham MB, Hernández LA \& Granger DN (1986). Xanthine oxidase and neutrophil infiltration in intestinal ischemia. American J ournal of Physiology, 251: G567G574.

3. Ysebaert DK, De Greef KE, Nouwen EJ, Verpooten GA, Eyskens EJ \& De Broe ME (1997). Influence of cyclosporin A on the damage and regeneration of the kidney after severe ischemia/reperfusion injury. Transplantation Proceedings, 29: 2348-
2351

4. Hoffman TF, Leiderer R, Harris AG \& Messmer K (1997). Ischemia and reperfusion in pancreas. Microscopy Research and Technique, 37: 557-571.

5. Gumina RJ, Newman PJ, Kenny D, Waltier DC \& Gross GJ (1997). The leukocyte cell adhesion cascade and its role in myocardial ischemia-reperfusion injury. Basic Research in Cardiology, 92: 201213.

6. Yanaka K, Spellman SR, McCarthy J B, Low WC \& Camarata PJ (1996). Reduction of brain injury using heparin to inhibit leukocyte accumulation in a rat model of transient focal cerebral ischemia. I. Protective mechanism. J ournal of Neurosurgery, 85: 1102-1107.

7. Romson J L, Hook BG, Kunkel GD, Abrams GD, Schork A \& Lucchesi BR (1983). Reduction of the extent of ischemic myocardial injury by neutrophil depletion in the dog. Circulation, 67: 1016-1023.

8. Huber AR, Kunkel SL, Todd RF \& Weiss SJ (1991). Regulation of transendothelial migration by endogenous interleukin-8. Science, 254: 99-102.

9. Kuijpers TW, Hajjert BC, Hart MHL \& Roos D (1992). Neutrophil migration across monolayers of cytokine-prestimulated en- 
dothelial cells: a role for platelet-activating factor and IL-8. J oumal of Cell Biology, 117: 565-572.

10. Edelstein CL, Ling H \& Schrier RW (1997). The nature of renal cell injury. Kidney International, 51: 1341-1351.

11. Neuhof $\mathrm{H}$, Neuhof $\mathrm{C}$, Neppl $\mathrm{H} \&$ \& Fritz $\mathrm{H}$ (1989). The role of proteinases in pulmonary vascular permeability. In: Fritz $\mathrm{H}$, Schmidt $Y \&$ Dietz G (Editors), The Kallikrein-Kinin System in Health and Disease. Limbach-Verlag, Braunschweig, Germany, 321-329.

12. Semerciöz $A$, Kelestimur $H$, Üstündag $B$, Baltaci AK, Yekeler $\mathrm{H}$, Sarsulmaz $\mathrm{M}$ \& Halifeoglu I (1997). Plasma renin activity and kidney damage in response to acute renal ischemia and ramipril treatment in ovariectomised and uninephrectomised rats. Medical Science Research, 25: 533536.

13. Schwab M, Bauer R \& Zwiener U (1997). The distribution of normal brain water content in Wistar rats and its increase due to ischemia. Brain Research, 749: 82-87.

14. Marin-Grez M \& Schaechtelin G (1982). The measurement of amidolytic activity in kidney homogenates for the estimation of renal kallikrein. Kidney International, 22: 697-701.

15. Bradford MM (1976). A rapid and sensitive method for the quantitation of microgram quantities of protein utilising the principle of protein-dye binding. Analytical Biochemistry, 72: 248-254.

16. Shoshan $Y \&$ Siegal MD (1996). Control of vasogenic edema in a brain tumor model: comparison between dexamethasone and superoxide dismutase. Neurosurgery, 39: 1206-1214.

17. Toyoda T, Suzuki S, Kassell NF \& Lee KS (1996). Intraischemic hypothermia attenuates neutrophil infiltration in the rat neocortex after focal ischemia-reperfusion injury. Neurosurgery, 39: 1200-1205.

18. Suzuki K, Ota H, Sasagawa S, Sakatami T \& Fujikura T (1983). Assay method for myeloperoxidase in human polymorphonuclear leukocytes. Analytical Biochemistry, 132: 345-352.

19. Ambrosio $G$ \& Tritto I (1999). Reperfusion injury: experimental evidence and clinical implications. American HeartJ ournal, 138 (Part 2): 69-75.

20. Lefer AM \& Lefer DJ (1993). Pharmacology of the endothelium in ischemia-reperfusion and circulatory shock. Annual Review of Pharmacology and Toxicology, 33: 71-90.

21. Noel AA, Fallek SR, Hobson 2nd RW \& Durán WN (1995). Inhibition of nitric oxide synthase attenuates primed microvascular permeability in the in vivo microcirculation. J ournal of Vascular Surgery, 22: 661670.

22. Proud D, MacGlashan J rDW, Newball HH, Schulmann ES \& Lichtenstein LM (1985). Immunoglobulin E-mediated release of kininogenase from purified human lung mast cells. American Review of Respiratory Disease, 132: 405-408.

23. Figueroa C \& Bhoola K (1989). Leukocyte tissue kallikrein: an acute phase signal for inflammation. In: Fritz $\mathrm{H}$, Schmidt $\mathrm{Y} \&$ \& Dietz $\mathrm{G}$ (Editors), The Kallikrein-Kinin System in Health and Disease. Limbach-
Verlag, Braunschweig, Germany, 311320.

24. Kaplan AP, Reddigari $S \&$ Silverberg $M$ (1989). Assessment of the plasma kininforming pathways in allergic diseases. In: Fritz H, Schmidt Y \& Dietz G (Editors), The Kallikrein-Kinin System in Health and Disease. Limbach-Verlag, Braunschweig, Germany, 143-153.

25. Bhoola KD, Figueroa $C D \&$ Worthy $K$ (1992). Bioregulation of kinins: kallikreins, kininogens and kininases. Pharmacological Reviews, 44: 1-80.

26. Bhoola KD (1996). Translocation of the neutrophil kinin moiety and changes in the regulation of kinin receptors in inflammation. Immunopharmacology, 33: 247256

27. Rothschild AM \& Castania A (1974). Lowering kininogens in rat blood by adrenaline and its inhibition by lympholytic agents, heparin and aspirin. British J ournal of Pharmacology, 50: 375-389.

28. Richards RI, Coghlan JP, Digby M Drinkwater CC, Lloyd C, Lyons I \& XiaoYun Z (1989). Molecular biology of the glandular kallikrein genes of mouse and man. In: Fritz $H$, Schmidt $Y \&$ Dietz G (Editors), The Kallikrein-Kinin System in Health and Disease. Limbach-Verlag, Braunschweig, Germany, 215-225.

29. Nolly H, Carretero OA \& Scicli AG (1993). Kallikrein release by vascular tissue. American J ournal of Physiology, 265 (Heart and Circulatory Physiology, 34): H1209$\mathrm{H} 1214$. 